\title{
Impact of Different Carbon Dioxide Concentrations in the Olfactory Response of Sipha flava (Hemiptera: Aphididae) and its Predators
}

\author{
Marcy G. Fonseca • Dayane R. Santos • \\ Alexander M. Auad
}

Revised: 6 August 2014 / Accepted: 8 August 2014 /

Published online: 27 August 2014

(C) Springer Science+Business Media New York 2014

\begin{abstract}
The increasing level $\mathrm{CO}_{2}$ may altered host plant physiology and hence affect the foraging behavior of herbivore insects and predator. Hence, the aim of this study was provides evidence that host plants grown at different levels of $\mathrm{CO}_{2}$ can alter the choice behavior of aphid, Sipha flava and their natural enemies, Cycloneda sanguinea and Diomus seminulus. The plant used was Pennisetum purpureum, cultivar Cameron Piracicaba growing in greenhouse (mean value of $\mathrm{CO}_{2}=440 \mathrm{ppm}$ ), climatic chamber with constant value of $\mathrm{CO}_{2}=500 \mathrm{ppm}$ and climatic chamber with fluctuating $\mathrm{CO}_{2}$ (mean value $=368 \mathrm{ppm}$ ). A glass Y-shape olfactometer was used to verify the insects responses towards elephant grass plants cultivated under different conditions. The aphids were statistically more attracted by plants grown with constant $\mathrm{CO}_{2}$ level $(500 \mathrm{ppm})$ than by plants grown with fluctuating $\mathrm{CO}_{2}$ level or plants grown in greenhouse. There was no difference in S. flava preference to non-infested versus infested plants by conspecifics. The predator $C$. sanguinea did not show difference between plants grown with constant $\mathrm{CO}_{2}$ level and infested or not with $S$. flava. However, the predator $D$. seminulus showed higher preference to plants grown with constant $\mathrm{CO}_{2}$ level and infested with $S$. flava. This study showed that the response of $S$. flava and its predators were affected by plants grown under different levels of $\mathrm{CO}_{2}$.
\end{abstract}

Keywords Aphid Elephant grass $\cdot \mathrm{CO}_{2}$ levels $\cdot$ Y-olfactometer

\section{Introduction}

For the last hundred years, the $\mathrm{CO}_{2}$ levels have been rising steadily, with an annual rate of increase of $1.5 \mathrm{ppmv}$ and the current concentration of $370 \mathrm{ppmv}$ (Intergovernmental Panel on Climate Change IPCC 2001). The levels of atmospheric $\mathrm{CO}_{2}$ are anticipated to double by the end of this century (Veteli et al. 2002).

M. G. Fonseca • D. R. Santos • A. M. Auad ( $\square)$

Entomology Laboratory, Embrapa Dairy Cattle Research Station, Juiz de Fora, MG, Brazil

e-mail: alexander.auad@embrapa.br 
Increasing levels of $\mathrm{CO}_{2}$ may affect the searching behaviour of herbivore insects due to differences in the $\mathrm{C}: \mathrm{N}$ rate from the host plants (Chen et al. 2005), and this difference in the $\mathrm{C}: \mathrm{N}$ may lead an change in the emission of volatile. It is not yet clear if the increasing amount of atmospheric $\mathrm{CO}_{2}$ increase or decrease the plant volatile emissions (Peñuelas and Llusia 2003), however, variations of volatile emissions have been registered in high $\mathrm{CO}_{2}$ levels depending on the plant (O'Neill et al. 2010).

Holopainen (2002) indicated that among 26 aphid host plant combinations reported, 6 cases indicated increased aphid performance and 5 cases indicated reduced aphid performance at elevated $\mathrm{CO}_{2}$, while 12 aphid host plant combinations at elevated $\mathrm{CO}_{2}$ did not differ from ambient $\mathrm{CO}_{2}$ level. There is strong evidence that aphids are sensitive to elevated levels of carbon dioxide. There exists increasing evidence that the rising atmospheric $\mathrm{CO}_{2}$ concentration may have a variety of direct and indirect effects on the trophic relationships between plants, their herbivores, and natural enemies (Stiling et al. 2002).

In Brazil the elephant grass, Pennisetum purpureum, is one of the most common forage used as cattle food (Xavier et al. 2001.), however this forage has been affected by aphid Sipha flava (Forbes) attack in greenhouses (Oliveira et al. 2009). Nowadays the predator Diomus seminulus (Mulsant) (Coleoptera: Coccinellidae) is found feeding on S. flava in grass forage cultivated in greenhouses (Auad et al. 2013), and Cycloneda sanguinea (Coleoptera: Coccinellidae) was found feeding on another aphid species in grass forage in the field (Auad, personal communication), suggesting that its natural enemies have great potential as a biological control agent of this aphid.

Therefore, study the searching behaviour this aphid and its natural enemies for plants that grew in high levels of $\mathrm{CO}_{2}$ is important for understand how the pest insects and the natural enemies will behave in future, when high concentrations of $\mathrm{CO}_{2}$ are expected to occur in our planet. Due to that, the aim of this study was provides evidence that host plants grown at different levels of $\mathrm{CO}_{2}$ can alter the choice behaviour of aphid, S. flava and their natural enemies, C. sanguinea and D. seminulus.

\section{Methods}

Insects and Plants

The aphid S. flava and the predators D. seminulus and C. sanguinea were obtained in forage plants cultivated in greenhouses at Embrapa Dairy Cattle Research Station, Brazil. The aphids were placed in Petri dishes $(13.5 \mathrm{~cm}$ in diameter and $1.5 \mathrm{~cm}$ in length) containing agar medium covered with pieces of elephant grass leaves, Roxo de Botucatu cultivar, and were kept in climatic chambers at $25^{\circ} \mathrm{C}, 12 \mathrm{~h}$ of photophase and $70 \%$ relative humidity. After $24 \mathrm{~h}$ the nymphs were moved to another Petri dish $(9 \mathrm{~cm}$ in diameter and $1.5 \mathrm{~cm}$ in length), and after 9 to 13 days, period that the insects need to be adults (Oliveira et al. 2009), the aphids were used to perform the bioassays. The age of the predators were not known since they were collected directly from the rearing in the greenhouse.

The plant that was used to perform the olfactometer tests was $P$. purpureum, cultivar Cameron Piracicaba. Plant cuttings were placed in plastic cups $(300 \mathrm{ml})$ containing soil, and kept growing in environments with different concentrations of $\mathrm{CO}_{2}$ : 1) greenhouse: 
mean value of $\mathrm{CO}_{2}=440 \mathrm{ppm}$ (minimum value $=384 \mathrm{ppm}$ and maximum value $=$ $924 \mathrm{ppm}$ ); 2) climatic chamber: constant value of $\mathrm{CO}_{2}=500 \mathrm{ppm}$; 3) climatic chamber : fluctuating $\mathrm{CO}_{2}$ (mean value $=368 \mathrm{ppm}$, minimum value $=163 \mathrm{ppm}$ and maximum value $=832 \mathrm{ppm}$ ). The plants were used when they were $56.55 \mathrm{~cm}$ high.

In the climatic chambers $(2.5 \times 2.20 \times 2.80 \mathrm{~m})$ the climatic parameters were $25^{\circ} \mathrm{C} \pm$ $2{ }^{\circ} \mathrm{C}, 70 \% \pm 10 \% \mathrm{UR}$, and 14:10 L:E photoperiod. In the greenhouse the values were not constant, with mean values of $23.8^{\circ} \mathrm{C}$ and $97.2 \% \mathrm{UR}$. The constant level of $\mathrm{CO}_{2}$ in one climatic chamber was kept by using an automatic monitoring system, COEL HW 4200 (Manaus-Amazonas, Brazil), and by using a $\mathrm{CO}_{2}$ injection system (using $\mathrm{CO}_{2}$ cilinders) to keep the concentration level that was needed. The level of $\mathrm{CO}_{2}$ fluctuating was registered every 2 min by a DataLogger, and the data were transferred to a computer using a HOBOware software (OnsetCo., Pocasset, Massachusetts, USA) to get the mean values of $\mathrm{CO}_{2}$ during the test period.

\section{Bioassays}

A glass Y-shape olfactometer (diameter: $1 \mathrm{~cm}$; main and side arms: $10 \mathrm{~cm}$ length each) was used to verify the insects response towards elephant grass plants cultivated under different conditions. There was a continuous air flow of $0.6 \mathrm{~L} / \mathrm{min}$ for the aphids and $2 \mathrm{~L} / \mathrm{min}$ for the predators, humidified and filtered previously with distilled water and activated charcoal. The main arm was connected by a teflon hose to a vacuum pump. Each olfactometer arm was connect by a silicone tube to individual glass chambers (42 $\mathrm{cm}$ height $\times 16 \mathrm{~cm}$ width) containing different odor sources. One insect was placed inside the main tube each time. A filter paper in Y-shaped was placed inside glass olfactometer for facilitate walk of the aphids. The filter paper was changed every aphid tested.

Three olfactometer bioassays were performed. The first bioassay was done to verify the aphid S. flava response towards plants that grew under different concentrations of $\mathrm{CO}_{2}$. The odor sources used as stimulus were: (i) plant grown in greenhouse versus pure air; (ii) plant grown with constant $\mathrm{CO}_{2}$ level (500 ppm) versus air; (iii) plant grown with fluctuating $\mathrm{CO}_{2}$ level versus air; (iv) plant grown in greenhouse versus plant grown with constant $\mathrm{CO}_{2}$ level (500 ppm); (v) plant grown in greenhouse versus plant grown with fluctuating $\mathrm{CO}_{2}$ level; (vi) plant grown with constant $\mathrm{CO}_{2}$ level $(500 \mathrm{ppm})$ versus plant grown with fluctuating $\mathrm{CO}_{2}$ level. For each treatment at least 80 S. flava adults with known ages were tested.

The second bioassay was done to verify the behaviour of the aphid $S$. flava to plants that grew in climatic chamber with different concentrations of $\mathrm{CO}_{2}$ and that were infested or not with conspecific insects. The odor sources used as stimulus were: (i) plant grown in greenhouse versus plant grown in greenhouse and infested with $S$. flava; (ii) versus plant grown with constant $\mathrm{CO}_{2}$ level (500 ppm) versus plant grown with constant $\mathrm{CO}_{2}$ level (500 ppm) and infested with $S$. flava; (iii) plant grown with fluctuating $\mathrm{CO}_{2}$ level $\mathrm{CO}_{2}$ versus plant grown with fluctuating $\mathrm{CO}_{2}$ level and infested with $S$. flava. The plants were infested with 200S. flava nymphs and/or adults $2 \mathrm{~h}$ before the tests were performed. For each treatment at least $65 \mathrm{~S}$. flava adults with known ages were tested.

The third bioassay aimed to investigate the searching behaviour predators, $D$. seminulus and $C$. sanguinea, towards plants cultivated in climatic chamber with $500 \mathrm{ppm}$ of $\mathrm{CO}_{2}$ infested or not with $S$. flava. The adult aphids were placed individually inside glass tubes without food during $2 \mathrm{~h}$ before the tests. The odor sources used 
as stimulus were: (i) plant grown with constant $\mathrm{CO}_{2}$ level (500 ppm) versus plant grown with constant $\mathrm{CO}_{2}$ level (500 ppm) infested with $200 \mathrm{~S}$. flava nymphs/adults. For each treatment 50 adults $D$. seminulus and 34 adults $C$. sanguinea were tested.

The aphids were placed individually inside glass tubes without food during $2 \mathrm{~h}$ before the tests. In all olfactometer tests each adult was tested only once and after the tests was placed back into the rearing. After testing 5 insects the olfactometer was cleaned with alcohol and placed in an oven at $50{ }^{\circ} \mathrm{C}$ during $10 \mathrm{~min}$. The position of the olfactometer arms was changed after testing 10 insects to avoid any external interference. The non infested plants were replaced after testing 10 insects, and the infested plants were replaced after testing 20 insects. It was considered as a response when the insect walked against the air flow and reached one of the arms with the odor source. And it was considered as a non response when the insect did not walk or did not reach any arm with odor source during a period of $15 \mathrm{~min}$.

The number of insects attracted to the sources was analyzed by using Chi squared test (BioEstat Program, Ayres et al. 2003). The insects that did not choose any source were not included in the comparison.

\section{Results}

Adults of $S$. flava were not significantly attracted by plants that grew in greenhouse when comparing with pure air $\left(\chi^{2}=0.49 ;\right.$ d.f $\left.=1 ; \mathrm{P}=0.48\right)$. However, the aphids preferred the plants grown with constant $\mathrm{CO}_{2}$ level $(500 \mathrm{ppm})\left(\chi^{2}=7.62 ;\right.$ d.f $=1 ; \mathrm{P}=$ $0.005)$ and the plants grown with fluctuating $\mathrm{CO}_{2}$ level $\left(\chi^{2}=7.618 ; \mathrm{d} . \mathrm{f}=1 ; \mathrm{P}=0.005\right)$ when comparing with pure air. The aphids did not prefer plants grown in greenhouse compared with plants grown with fluctuating $\mathrm{CO}_{2}$ level $\left(\chi^{2}=2.56\right.$; d.f $\left.=1 ; \mathrm{P}=0.109\right)$. On the other hand the aphids preferred plants grown with constant $\mathrm{CO}_{2}$ level instead of plants grown in greenhouse $\left(\chi^{2}=8.07 ; \mathrm{d} . \mathrm{f}=1 ; \mathrm{P}=0.004\right)$, and preferred plants grown with constant $\mathrm{CO}_{2}$ level instead of plants grown with fluctuating $\mathrm{CO}_{2}$ level $\left(\chi^{2}=6.03\right.$; d.f $=1 ; \mathrm{P}=0.014$ ) (Fig. 1).

There was no difference on aphids response to plants grown with constant $\mathrm{CO}_{2}$ level infested or not with conspecific $\left(\chi^{2}=0.49 ; \mathrm{d} . \mathrm{f}=1 ; \mathrm{P}=0.50\right)$, or to plants grown with fluctuating $\mathrm{CO}_{2}$ level infested or not with conspecific $\left(\chi^{2}=2.76 ; \mathrm{d} . \mathrm{f}=1 ; \mathrm{P}=0.09\right)$, or to plants grown in greenhouse infested or not with conspecifics $\left(\chi^{2}=0.48 ; \mathrm{d} . \mathrm{f}=1 ; \mathrm{P}=0.48\right)$ (Fig. 2).

The predator $C$. sanguinea did not show preference among plants grown with constant $\mathrm{CO}_{2}$ level infested or not with $S$. flava $\left(\chi^{2}=0.54\right.$; d.f $\left.=1 ; \mathrm{P}=0.45\right)$. However, the predator $D$. seminulus preferred plants grown with constant $\mathrm{CO}_{2}$ level infested with $S$. flava when comparing with plants not infested with this aphid $\left(\chi^{2}=36.96\right.$; d.f $=1$; $P<0.0001$ ) (Fig. 3).

\section{Discussion}

The results demonstrated that there was olfactory preference of $S$. flava by plants grown at constant high concentration of $\mathrm{CO}_{2}(500 \mathrm{ppm})$ when compared to plants grown in another environment, suggesting that high level $\mathrm{CO}_{2}$ may have altered host plant 
No Choice

$\mathrm{n}=80$

$\mathrm{n}=80$

$\mathrm{n}=80$

$\mathrm{n}=80$

$\mathrm{n}=80$

$\mathrm{n}=85$

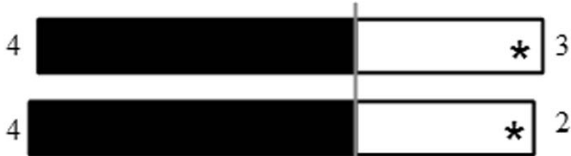

\section{$\begin{array}{lllllllll}80 & 60 & 40 & 20 & 0 & 20 & 40 & 60 & 80\end{array}$}

Olfactory responses of Sipha flava (\%)

Fig. 1 Olfactory responses of Sipha flava to air (1), elephant grass plants grown in greenhouse (mean value $=440 \mathrm{ppm}$ ) (2), elephant grass plants grown climatic chamber with fluctuating $\mathrm{CO}_{2}$ value (mean value $=384 \mathrm{ppm}$ ) (3) and elephant grass plants grown in climatic chamber with 500 ppm (4) in an Y olfactometer. *: significant $\left({ }^{*} P<0.05\right.$ in Chi-squared test) preference toward either odor source; $n s$ No significant; $n$ indicates the total number of aphids used in the bioassay including the individuals that did not show any preference for either odor source

physiology. Chen et al. (2004) reported that the rising $\mathrm{CO}_{2}$ levels may affect foraging behavior of herbivore insects because of altered host plant $\mathrm{C}: \mathrm{N}$ ratios.

Awmack et al. (1996) reported that the grain aphid Sitobion avenae Fabricius tended to select wheat plants grown at elevated $\mathrm{CO}_{2}$ levels, rather than the ambient condition. However, Aphis glycines Matsumura did not show preference between soybean plants with high $\mathrm{CO}_{2}(550 \mu \mathrm{mol} / \mathrm{mol})$ or with atmospheric level of $\mathrm{CO}_{2}(378 \mu \mathrm{mol} / \mathrm{mol})\left(\mathrm{O}^{\prime} \mathrm{Neill}\right.$ et al. 2010). According to Awmack et al. (1997); Hullé et al. (2010) the aphid response to

$$
\begin{aligned}
& \mathrm{n}=80 \\
& \mathrm{n}=80 \\
& \mathrm{n}=65
\end{aligned}
$$

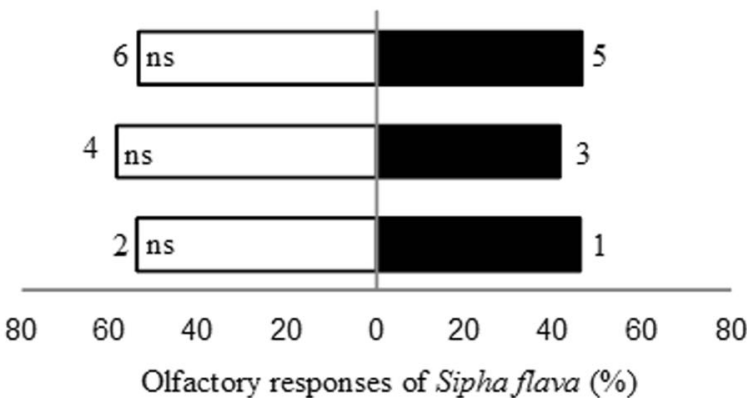

No Choice

Fig. 2 Olfactory responses of Sipha flava to elephant grass plants grown greenhouse (mean value $=440 \mathrm{ppm})$ without aphids (1), elephant grass plants grown greenhouse + aphids (2), elephant grass plants grown climatic chamber with fluctuating $\mathrm{CO}_{2}$ value (mean value $=384 \mathrm{ppm}$ ) without aphids (3), elephant grass plants grown climatic chamber with fluctuating $\mathrm{CO}_{2}$ value (mean value $=384 \mathrm{ppm}$ ) + aphids (4), elephant grass plants grown in climatic chamber with 500 ppm without aphids (5) and elephant grass plants grown in climatic chamber with $500 \mathrm{ppm}+$ aphids (6) in an Y olfactometer. *: significant $\left({ }^{*} P<0.05\right.$ in Chi-squared test) preference toward either odor source; $n s$ No significant; $n$ indicates the total number of aphids used in the bioassay including the individuals that did not show any preference for either odor source 


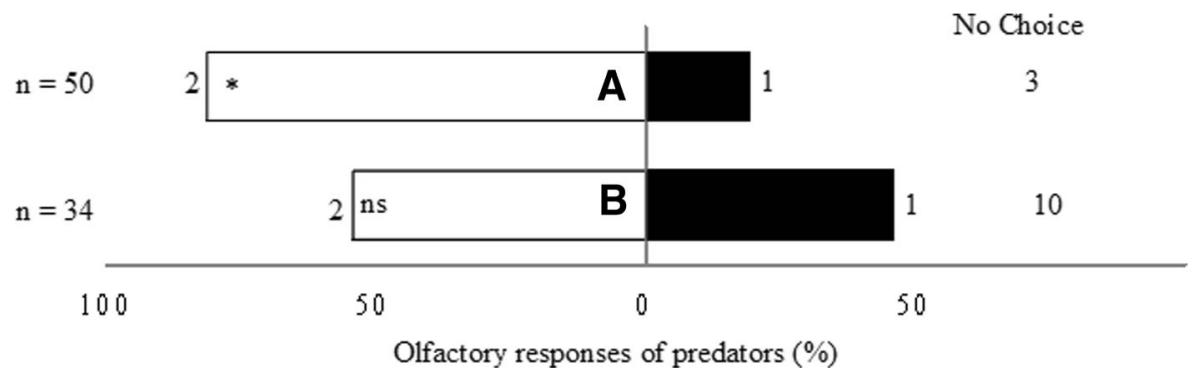

Fig. 3 Olfactory responses of Diomus seminulus (A) and Cicloneda sanguinea (B) to elephant grass plants grown in climatic chamber with $500 \mathrm{ppm}$ of $\mathrm{CO}_{2}$ without aphid (1) and elephant grass plants grown in climatic chamber with $500 \mathrm{ppm}$ of $\mathrm{CO}_{2}+$ aphids (2). *: significant $\left({ }^{*} P<0.05\right.$ in Chi-squared test) preference toward either odor source; $n s$ No significant; $n$ indicates the total number of aphids used in the bioassay including the individuals that did not show any preference for either odor source

high $\mathrm{CO}_{2}$ concentrations are not constant and depend on the aphid species, the host plant or may even not vary at all.

The plants that are colonized and damaged by herbivore insects produce a group of volatile organic compounds, including semiochemicals that act as repellents for pest insects. These semiochemicals indicate that the plant is already infested and thereby is less acceptable as a host (Pickett et al. 2006). The present study demonstrated that the aphids were not attracted to damaged plants by conspecifics regardless of the environment in which it was grown, showing that previous damage done by conspecifics does not enhance acceptance by another individuals.

Recently results obtained in olfactometer tests showed that the predator D. seminulus was more attracted to elephant grass plants infested with $S$. flava than to no infested plants (Auad et al. 2013). In the present study the same predator D. seminulus preferred plants infested with $S$. flava and that grew in an environment with $500 \mathrm{ppm}$ of $\mathrm{CO}_{2}$. This result suggests that the coccinellid searching behavior for the prey will not be affected by the plant that was grown with $500 \mathrm{ppm}$ of $\mathrm{CO}_{2}$, indicating that this predator has potential for control of the aphid $S$. flava under high levels of carbon dioxide in the atmosphere.

Nymphs of the predator Podisus maculiventris preferred the odor of cabbage plants damaged by Plutella xylostella that grew with atmospheric $\mathrm{CO}_{2}$ level (360 $\mu \mathrm{mol} \mathrm{mol}^{-1}$ ), but showed low preference between damaged or health plants cultivated with high $\mathrm{CO}_{2}$ level $\left(720 \mu \mathrm{mol} \mathrm{mol}^{-1}\right)$ (Vuorinem et al. 2004). According to the authors there was a great reduction of the compound (Z)-3-decenyl acetate on damaged cabbage plants cultivated with high $\mathrm{CO}_{2}$ level, which can explain the decreasing on $P$. maculiventris searching behavior. The present study suggest that there were changes on the volatile emission of damaged elephant grass plants and grown with high $\mathrm{CO}_{2}$ level, which could be responsible for the increase of the searching behavior of $D$. seminulus e and not preference of $C$. sanguinea.

Our result showed the first evidence that the response of $S$. flava and its predators were affected by plants grown under different levels of $\mathrm{CO}_{2}$.

Acknowledgments We thank the Conselho Nacional de Desenvolvimento Científico e Tecnológico (CNPq, Brazil), Fundação de Amparo à Pesquisa do Estado de Minas Gerais (FAPEMIG, Brazil) for supporting our research. 


\section{References}

Auad AM, Fonseca MG, Monteiro PH, Resende TT, Santos DR (2013) Aspects of the biology of the lady Beetle Diomus seminulus (Coleoptera: Coccinellidae): a potential biocontrol agent against the yellow sugarcane aphid in Brazil. Ann Entomol Soc Am 106:243-248

Awmack CS, Harrington R, Leather SR, Lawton JH (1996) The impacts of elevated $\mathrm{CO}_{2}$ on aphid-plant interactions. Aspect Appl Biol 45:317-322

Awmack CS, Woodcock CM, Harrington R (1997) Climate change may increase vulnerability of aphids to natural enemies. Ecol Entomol 22:366-368

Ayres M, Ayres JR M, Ayres DL, Santos AS (2003) BioEstat 3.0, Aplicações estatísticas nas áreas das ciências biológicas e médicas. Sociedade Civil Maramirauá, Belém, Brasil

Chen FJ, Wu G, Ge F (2004) Impacts of elevated CO2 on the population abundance and reproductive activity of aphid Sitobion avenae Fabricius feeding on spring wheat. J Appl Entomol 128:723-730

Chen F, Ge F, Parajulee MN (2005) Impact of elevated $\mathrm{CO}_{2}$ on tri-trophic interaction of Gossypium hirsutum, Aphis gossypii, and Leis axyridis. Environ Entomol 34:37-46

Holopainen JK (2002) Aphid response to elevated ozone and $\mathrm{CO}_{2}$. Entomol Exp Appl 104:137-142

Hullé M, Coeur D'acier A, Bankhead-Dronnet S, Harrington R (2010) Aphids in the face of global changes. C R Bio 333:497-503

Oliveira AS, Souza B, Auad AM, Silva MS, Souza LS, Carvalho CA (2009) Desenvolvimento e reprodução de Sipha flava (Forbes) (Hemiptera: Aphididae) em diferentes temperaturas. Neotrop Entomol 38:311-316

Intergovernmental Panel on Climate Change (IPCC) (2001) Climate change 2001: the scientific basis. Report from Working Group. Intergovernmental Panel on Climate Change, Geneva, Switzerland

O'Neill BF, Zangerl AR, Delucia EH, Berenbaum MR (2010) Olfactory preferences of Popillia japonica, Vanessa cardui, and Aphis glycines for Glycine max grown under elevated $\mathrm{CO}_{2}$. Environ Entomol 39: 1291-1301

Peñuelas J, Llusia J (2003) BVOCs: plant defense against climate warming? Trends Plant Sci 8:105-109

Pickett JA, Bruce TJA, Chamberlain K, Hassanali A, Khan ZR, Matthes MC, Napier JA, Wadhams LJ, Woodcock CM (2006) Plant volatiles yielding new ways to exploit plant defence. In: Dicke M, Takken W (eds) Chemical Ecology: From Gene to Ecosystem. Springer, Netherlands pp, pp 161-173

Stiling P, Cattell M, Moon DC, Rossi A, Hungate BA, Hymus G, Drake B (2002) Elevated atmospheric CO2 lowers herbivore abundance, but increases leaf abscission rates. Glob Change Biol 8:658-667

Veteli TO, Kuokkanen K, Julkunnen TR, Roininen H, Tahvanainen J (2002) Effects of elevated CO2 and temperature on plant growth and herbivore defensive chemistry. Glob Change Biol 8:1240-1252

Vuorinem T, Nerg AM, Ibrahim MA, Reddy GVP, Holopainen JK (2004) Emission of Plutella xylostellainduced compounds from cabbages grown at elevated $\mathrm{CO}_{2}$ and behavior of the natural enemies. Plant Physiol 135:1984-1992

Xavier DF, Carvalho MM, Botrel MA, Freitas VP, Verneque RS (2001) Efeito do manejo pós-plantio no estabelecimento de pastagem de capim-elefante. Rev Bras Zootech 30:1200-1203 